\title{
KARAKTERISTIK SIFAT KIMIA TANAH DAN STATUS KESUBURAN TANAH PADA AGROFORESTRI TANAMAN SAYURAN BERBASIS Eucalyptus Sp.
}

\author{
Characteristics of Soil Chemical Properties and Soil Fertility Status of Vegetables \\ Agroforestry Based on Eucalyptus Sp.
}

Gunawan $^{1 *}$, Nurheni Wijayanto ${ }^{1}$, Sri Wilarso Budi $\mathbf{R}^{1}$

(Diterima Februari 2018/Disetujui Desember 2018)

\begin{abstract}
Ministry of Environment and Forestry launched a flood prevention program in Garut regency with 3 rehabilitation programs namely conventional tree planting (Conventional Crops), Air Nurseries, and agroforestry forests. Choice of type is the key to success of agroforestry. The most widely planted species in the Cimanuk watershed are cultivars combined with vegetable crops. This study aims to analyze the soil chemical fertility status on eucalyptus-based vegetable agroforestry patterns in some age classes and to analyze changes in soil fertility status after harvest. The soil fertility status is chemically classified in all plots either monoculture or under eucalyptus age 2, 4, and 6 years.. Agroforestry planting patterns can improve the soil fertility status chemically into high categories. Prior to cultivation the mean value of CEC was 24.72 me / 100gr (moderate), Saturation Base 64.19\% (high), P2O5 35.57 me / 100gr (very high), K2O $213.48 \mathrm{me} / 100 \mathrm{gr}$ (very high), and C-org $3.54 \%$ (high). After harvest the average value of CEC is $25.36 \mathrm{me} / 100 \mathrm{~g}$ (high), Saturation Base $66.04 \%$ (high), $\mathrm{P}_{2} \mathrm{O}_{5} 77.05$ me/100g (very high), $\mathrm{K}_{2} \mathrm{O} 652.83$ me/100g (very high), and C-org $3.84 \%$ (high).
\end{abstract}

Key words: agroforestry, Cimanuk watershed, vegetable

\section{PENDAHULUAN}

Banjir bandang di Kabupaten Garut pada September 2016 menurut analisis KLHK disebabkan oleh rusaknya kawasan hutan lindung di Hulu DAS Cimanuk. Luas DAS Cimanuk Hulu 59,000 ha, dari luas tersebut yang idealnya $30 \%$ dalam kondisi vegetasi tetap hutan namun kondisinya sekarang hanya $19 \%$ yang berupa hutan. Pertanian lahan kering dengan mayoritas tanaman sayuran yang mendominasi sebesar $42 \%$ dan persawahan 22\% (Koesmawardhani 2017). Menurut Badan Pengelolaan Lingkungan Hidup Daerah (BPLHD) Jawa Barat kerusakan hutan akibat alih fungsi lahan pada hulu DAS Cimanuk berada di Gunung Papandayan dan Cikuray di wilayah Kecamatan Cikajang, Kabupaten Garut (Masnurdiansyah 2016).

Kementerian Lingkungan Hidup dan Kehutanan (KLHK) melalui arahan Presiden dan Wakil Presiden RI, melakukan penanganan Daerah Aliran Sungai (DAS) pasca bencana banjir di Kabupaten Garut bulan September 2016 lalu, KLHK beserta Pemerintah Daerah telah melaksanakan pemulihan DAS melalui Rehabilitasi Hutan dan Lahan (RHL) serta pembuatan bangunan Konservasi Tanah dan Air (KTA). Kegiatan RHL dilaksanakan dengan 3 (tiga) pola, yakni penanaman pohon secara konvensional (Reboisasi Konvensional), penebaran benih melalui udara (Aerial Seeding), dan hutan rakyat agroforestri (KLHK 2017).

Agroforestri merupakan sistem pengelolaan sumber daya alam yang berbasis ekologi dengan

\footnotetext{
${ }^{1}$ Departemen Silvikultur, Fakultas Kehutanan IPBUniversity

* Penulis korespondensi:

e-mail: gunawanbppta@gmail.com
}

mengintegrasikan tanaman pertanian dengan tanaman kehutanan dalam kesatuan lanskap. Agroforestri mampu menganekaragamkan serta melestarikan produksi lahan sehingga dapat meningkatkan manfaat sosial, ekonomi, dan ekologi lahan pada semua tingkatan. Pola agroforestri melibatkan berbagai macam tanaman dengan interaksi yang tinggi antara tanaman kehutanan dan tanaman pertanian. Agroforestri dapat dilakukan melalui penanaman pohon pada lahan pertanian maupun penanaman tanaman pertanian pada lahan hutan (FAO 2006, Suryanto et al. 2006).

Pemilihan jenis tanaman dalam sistem agroforestri memegang peranan penting dalam pembangunan agroforestri. Basis ilmu agroforestri terletak pada kompetisi sumberdaya (cahaya, air, nutrisi), kompleksitas (sosial, ekonomi, dan ekologi), keuntungan dari sistem dan keberlanjutan (konservasi tanah, peningkatan biodiversitas dan keseimbangan $\mathrm{CO}_{2}$ ). Keberadaan berbagai jenis tanaman pada sistem agroforestri mengakibatkan terjadinya interaksi antara setiap tanaman. Interaksi tersebut dapat berupa interaksi positif (saling mendukung) maupun interaksi negatif (kompetitif). Pemilihan jenis pohon harus didasarkan pada sifat dan bentuk pohon yang berpengaruh terhadap tanaman semusim (Sanchez 1995, Hairiah et al. 2000, Sabarnurdin et al. 2004).

Eucalyptus merupakan jenis tanaman yang banyak ditanam oleh masyarakat di wilayah Hulu DAS Cimanuk. Tanaman eucalyptus tersebut ditanam dalam sistem agroforestri dengan tanaman sayuran. Jenis tanaman sayuran yang digunakan dalam sistem agroforestri tersbut antara lain: wortel, kubis, bawang daun, kentang, cabai, dan tomat. Tanaman eucalyptus banyak digunakan sebagai tanaman pokok (utama) 
dalam pola agroforestri terutama di dataran tinggi. Tanaman eucalyptus di kombinasikan dengan tanaman kopi dapat meningkatkan produktivitas tanaman kopi dibandingan dengan tanaman kopi yang dikombinasikan dengan tanaman suren. Pola agroforestri kombinasi tanaman eucalyptus dengan kopi mempunyai nilai paling besar pada pembobotan model agroforestri kombinasi tanaman lain yang dilakukan di dataran tinggi Dieng (Fathurrohmah 2014, Pujiwinarko 2015).

Eucalyptus banyak digunakan sebagai tanaman hutan dalam sistem agroforestri di lahan pertanian dengan tanaman pangan (Lisanework et al. 1993, Malik 2004). Pengunaan eucalyptus dalam agroforestri didasarkan pada sifat eucalyptus yaitu: karena pertumbuhannya yang cepat, kemampuan adaptasi yang lebih luas dan produktivitasnya tinggi. Namun demikian, masih ada kontroversi mengenai fungsi ekologis eucalyptus, yaitu dapat mengurangi keragaman jenis tumbuhan bawah dan produktivitas tanaman bawah tegakan (Bhatt 1990, Lisanework et al. 1993, Moradshahi 2003). Keberadaan tanaman eucalyptus pada berbagai kelas umur dan pola penanaman agroforestri akan membawa perubahan status kesuburan tanah. Informasi status kesuburan tanah pada tegakan eucalyptus dan agroforestri eucalyptus masih terbatas. Tujuan penelitian ini adalah menganalisis status kesuburan tanah secara kimia dan perubahan status kesuburan tanah setelah panen di beberapa kelas umur pada pola agroforestri sayuran berbasis eucalyptus.

\section{METODE PENELITIAN}

\section{Waktu dan Tempat Penelitian}

Penelitian ini dilaksanakan di Desa Mekar Jaya, Kecamatan Cikajang, Kabupaten Garut. Analisis sifat kimia tanah dilakukan di Fakultas Pertanian Universitas Jenderal Soedirman Purwokerto. Penelitian ini dilaksanakan pada bulan Mei sampai November 2017.

\section{Alat dan Bahan}

Bahan yang digunakan dalam penelitian ini adalah bibit tanaman sayuran jenis kubis varietas F1 Sharira dan benih wortel unggulan lokal, serta tanaman eucalyptus berumur 2 tahun, 4 tahun dan 6 tahun, pupuk organik dan anorganik, pestisida, fungisida, dan insektisida. Alat yang digunakan dalam penelitian ini adalah cangkul, bor, dan kantong plastik.

\section{Pelaksanaan Penelitian}

Penelitian ini dilaksanakan dengan mengambil sampel tanah pada plot monokultur, tegakan eucalyptus kelas umur 2, 4, dan 6 tahun. Pengambilan tanah dilakukan pada sebelum penanaman dan sesudah panen tanaman sayuran. Pengambilan tanah dilakukan secara komposit dengan kedalaman $0-20 \mathrm{~cm}$ pada setiap plot diambil dari 5 titik berbeda untuk mewakili keseluruhan plot. Setelah pengambilan sampel tanah pertama kemudian dilakukan penanaman tanaman sayuran (wortel dan kubis) pada semua plot. Pemupukan awal pada tanaman kubis menggunakan pupuk organik 5 kg.m ${ }^{-1}$, Urea 87, ZA 187, SP36 311, KCl 90 kg.ha-1. Pemupukan lanjutan pada usia 2 minggu setelah tanam

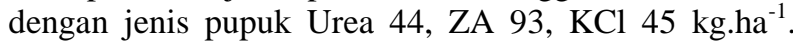
Dosis yang sama digunakan pada pemupukan lanjutan 4 minggu setelah tanam dan 8 minggu setelah tanam. Pemupukan awal pada tanaman wortel pupuk yang digunakan organik $2.5 \mathrm{~kg} . \mathrm{m}^{-1}$, Urea 249, SP36 311, KCl $112 \mathrm{~kg} \cdot \mathrm{ha}^{-1}$. Pemupukan lanjutan dilakukan pada 4 dan 6 minggu setelah tanam dengan jenis pupuk Urea 124, $\mathrm{KCl} 56$ kg.ha- ${ }^{-1}$ (Susila 2006). Pada saat panen kubis dan wortel dilakukan pengambilan sampel tanah kembali dengan metode yang sama pada saat sebelum penanaman. Analisis sampel tanah dilakukan pada sifat kimia tanah sesuai Tabel 1.

\section{Analisis Data}

Analisis data dilakukan secara tabulasi dan mendeskripsikan sifat kimia tanah. Penilaian status kesuburan tanah mengacu pada kriteria penilaian data analisis tanah dan kombinasi beberapa sifat kimia tanah dan status kesuburan tanahnya (PPT 1995)

\section{HASIL DAN PEMBAHASAN}

\section{HASIL}

\section{Kondisi Umum}

Luas lahan $1.512 \mathrm{~m}^{2}$ yang di bagi dalam 4 lokasi masing-masing lokasi luasnya $378 \mathrm{~m}^{2}$. Lokasi pertama merupakan plot monokultur sayuran berada di koordinat 10749'43.401'BT, 7²3'28.017'LS; lokasi kedua plot agroforestri tanaman sayuran dengan eucalyptus umur 2 tahun berada di koordinat 10749'43.806”BT, 7²3’28.256"LS; lokasi ketiga plot agroforestri tanaman sayuran dengan eucalyptus umur 4 tahun berada di koordinat $107^{\circ} 49^{\prime} 39.867^{\prime \prime} \mathrm{BT}, 7^{\circ} 233^{\prime} 27.595^{\prime \prime} \mathrm{LS}$; dan

Tabel 1 Jenis analisis sifat kimia tanah yang dilakukan

\begin{tabular}{|c|c|c|}
\hline No & Parameter pengujian & Metode yang digunakan \\
\hline 1 & $\mathrm{pH} \operatorname{tanah} \mathrm{H}_{2} \mathrm{O}$ & Ditetapkan dengan menggunakan $\mathrm{pH}$ meter dengan perbandingan tanah dengan pelarut $1: 1$ \\
\hline 2 & C-organik & $\begin{array}{l}\text { Ditetapkan dengan menggunakan destruksi basah dan menggunakan kalium bichromat } \\
\text { menurut metode Walkley and Black }\end{array}$ \\
\hline 3 & $\mathrm{~N}$ total & $\mathrm{N}$ total ditetapkan dengan metode Kjehldahl \\
\hline 4 & $\mathrm{P}_{2} \mathrm{O}_{5}$ Tersedia & $\begin{array}{l}\text { Fosfat total }(\mathrm{mg} / 100 \mathrm{~g}) \text { ditetapkan dengan menggunakan ekstraksi } \mathrm{HCl} 25 \% \text {, sedangkan fosfat } \\
\text { tersedia }(\mathrm{ppm}) \text { ditetapkan dengan menggunakan ekstraksi Bray }\end{array}$ \\
\hline 5 & $\mathrm{~K}_{2} \mathrm{O}$ & Kalium total ditetapkan dengan menggunakan ekstraksi $25 \% \mathrm{HCl}$ \\
\hline 6 & $\mathrm{Ca}, \mathrm{Mg}, \mathrm{K}, \mathrm{Na}$ & $\begin{array}{l}\text { Susunan kation (ca, } \mathrm{Mg}, \mathrm{Na} \text { dan } \mathrm{K} \text { ) ditetapkan dengan penjenuhan memakai amonium asetat } 1 \\
\mathrm{~N} \mathrm{pH} \text { 7.0. }\end{array}$ \\
\hline 7 & KTK & Ditetapkan dengan menjenuhkan menggunakan amonium asetat $1 \mathrm{~N} \mathrm{pH} 7.0$ (standar) \\
\hline 8 & $\mathrm{~KB}$ & Dihitung berdasarkan jumlah basa-basa di bagi KTK dikalikan 100 \\
\hline
\end{tabular}


lokasi ke empat plot agroforestri tanaman sayuran dengan eucalyptus berada di koordinat 10749'42.826'BT, 7²3'21.531'’LS.

\section{Status kesuburan tanah pada plot monokultur}

Plot monokultur dipilih lokasi yang bersebelahan dengan plot agroforestri eucalyptus umur 2 tahun. Hasil analisis sifat kimia tanah menunjukan bahwa $\mathrm{pH}$ tanah pada plot monokultur bersifat masam. Penanaman tanaman sayuran mampu meningkatkan $\mathrm{pH}$ tanah, kandungan C-organik, Rasio $\mathrm{C} / \mathrm{N}, \mathrm{P}_{2} \mathrm{O}_{5}, \mathrm{~K}_{2} \mathrm{O}$, dan $\mathrm{K}$. Namun ada beberapa unsur hara yang mengalami penurunan setelah penanaman tanaman sayuran antara lain $\mathrm{N}$ total, $\mathrm{Ca}, \mathrm{Mg}$, $\mathrm{Na}, \mathrm{KTK}$, dan KB. Hasil lengkap analisis sifat kimia tanah pada plot monokultur dapat dilihat pada Tabel 2

\section{Status kesuburan tanah pada plot agroforestri umur 2 tahun}

Plot agroforestri umur 2 tahun hasil analisis sifat kimia menunjukan bahwa sifat kimia tanah pada beberapa parameter mengalami perubahan sebelum dan sesudah penanaman. beberapa parameter yang mengalami peningkatan antara lain rasio $\mathrm{C} / \mathrm{n}, \mathrm{P}_{2} \mathrm{O}_{5}$ tersedia, $\mathrm{K}_{2} \mathrm{O}, \mathrm{Ca}, \mathrm{Mg}, \mathrm{K}, \mathrm{KTK}$ dan $\mathrm{KB}$, sedangkan parameter yang mengalami penurunan adalah $\mathrm{pH}, \mathrm{C}$ organik, $\mathrm{N}$ total, dan $\mathrm{Na}$. Hasil analisis sifat kimia tanah selengkapnya dapat dilihat pada Tabel 3.

\section{Status kesuburan tanah pada plot agroforestri umur 4 tahun}

Plot agroforestri umur 4 tahun hasil analisis sifat kimia menunjukan bahwa sifat kimia tanah pada beberapa parameter mengalami perubahan sebelum dan sesudah penanaman. beberapa parameter yang mengalami peningkatan antara lain rasio $\mathrm{pH}, \mathrm{C}$-organik, rasion $\mathrm{C} / \mathrm{N}, \mathrm{N}$ total, $\mathrm{P}_{2} \mathrm{O}_{5}$ tersedia, $\mathrm{K}_{2} \mathrm{O}, \mathrm{Ca}, \mathrm{Mg}, \mathrm{K}$, $\mathrm{KTK}$, sedangkan parameter yang mengalami penurunan adalah $\mathrm{Na}$, dan $\mathrm{KB}$. Hasil analisis sifat kimia tanah selengkapnya dapat dilihat pada Tabel 4.

\section{Status kesuburan tanah pada plot agroforestri umur 6 tahun}

Plot agroforestri umur 6 tahun hasil analisis sifat kimia menunjukan bahwa sifat kimia tanah pada beberapa parameter mengalami perubahan sebelum dan sesudah penanaman. beberapa parameter yang mengalami peningkatan antara lain rasio $\mathrm{pH}, \mathrm{C}$-organik, rasio $\mathrm{C} / \mathrm{N}, \mathrm{P}_{2} \mathrm{O}_{5}$ tersedia, $\mathrm{K}_{2} \mathrm{O}, \mathrm{Ca}, \mathrm{Mg}, \mathrm{K}, \mathrm{KTK}$, sedangkan parameter yang mengalami penurunan adalah $\mathrm{N}$ total dan $\mathrm{Na}$. Hasil analisis sifat kimia tanah selengkapnya dapat dilihat pada Tabel 5.

Untuk melakukan penilian terhadap penentuan status kesuburan sifat kimia tanah Pusat Penelitian Tanah Bogor telah mengembangkannya melalui petunjuk teknis evaluasi kesuburan tanah dengan mengacu kepada status KTK tanah, nilai kejenuhan basa,

Tabel 2 Hasil analisis sifat kimia tanah pada plot monokultur

\begin{tabular}{clcccr}
\hline \multirow{2}{*}{ No } & \multirow{2}{*}{ Parameter Pengujian } & Satuan & \multicolumn{2}{c}{ Plot Monokultur } & \multirow{2}{*}{ Perubahan } \\
\cline { 4 - 5 } & & & Sebelum & \multicolumn{1}{c}{ Setelah } & \\
\hline 1 & $\mathrm{pH} \mathrm{H} \mathrm{H}_{2} \mathrm{n}$ & $5.45(\mathrm{~m})$ & $5.71(\mathrm{am})$ & 0.26 \\
2 & $\mathrm{C}$-organik & $\%$ & $2.09(\mathrm{~s})$ & $2.67(\mathrm{~s})$ & 0.58 \\
3 & Rasio C/N & & $7.13(\mathrm{r})$ & $9.67(\mathrm{r})$ & 2.54 \\
4 & $\mathrm{~N}$ total & & $0.29(\mathrm{~s})$ & $0.28(\mathrm{~s})$ & -0.01 \\
5 & $\mathrm{P}_{2} \mathrm{O}_{5}$ Tersedia & $\mathrm{ppm}$ & $15.20(\mathrm{r})$ & $26.34(\mathrm{~s})$ & 11.14 \\
6 & $\mathrm{~K} 2 \mathrm{O}$ & $\mathrm{ppm}$ & $124.34(\mathrm{st})$ & $293.43(\mathrm{st})$ & 169.09 \\
7 & $\mathrm{Ca}$ & $\mathrm{me}$ & $16.74(\mathrm{t})$ & $12.72(\mathrm{t})$ & -4.02 \\
8 & $\mathrm{Mg}$ & $\mathrm{me}$ & $7.26(\mathrm{t})$ & $5.00(\mathrm{t})$ & -2.26 \\
9 & $\mathrm{~K}$ & $\mathrm{me}$ & $0.23(\mathrm{~s})$ & $0.68(\mathrm{t})$ & 0.45 \\
10 & $\mathrm{Na}$ & $\mathrm{me}$ & $0.38(\mathrm{~s})$ & $0.21(\mathrm{r})$ & -0.17 \\
11 & $\mathrm{KTK}$ & $\mathrm{me}$ & $31.21(\mathrm{t})$ & $25.84(\mathrm{t})$ & -5.37 \\
12 & $\mathrm{~KB}$ & $\%$ & $78.82(\mathrm{st})$ & $72.02(\mathrm{st})$ & -6.80 \\
\hline
\end{tabular}

$\mathrm{m}$ : masam, am: agak masam, $\mathrm{r}:$ rendah, $\mathrm{s}:$ sedang, $\mathrm{t}$ : tinggi, st : sangat tinggi
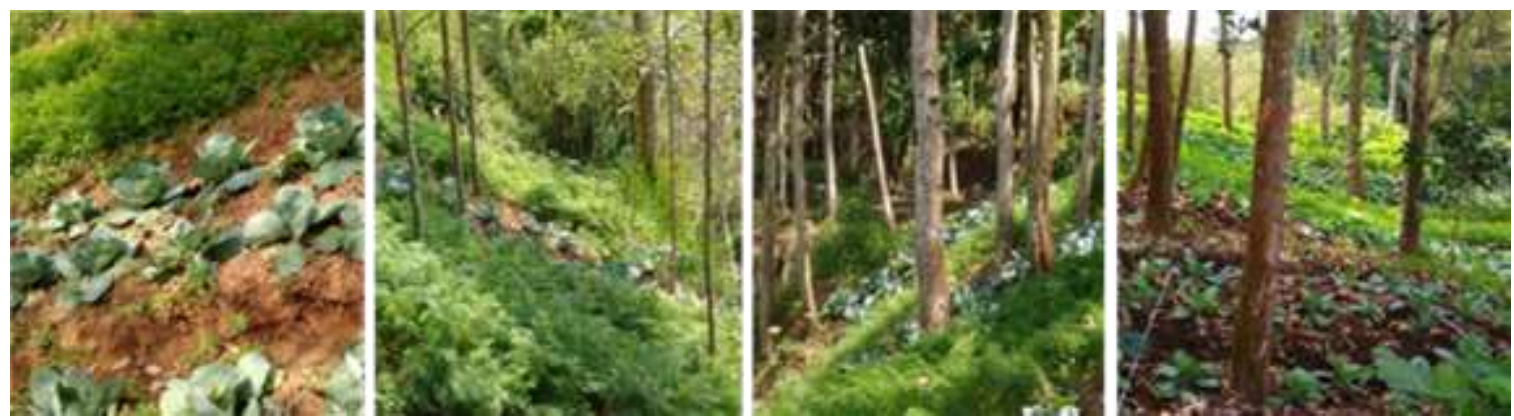

Gambar 1 Kondisi tanaman umur 6 MST masing-masing perlakuan (A) monokultur (B) agroforestri sayuran dan eucalyptus umur 2 tahun (C) agroforestri sayuran dan Eucalyptus umur 4 tahun (D) agroforestri sayuran dan eucalyptus umur 6 tahun 
kandungan bahan organik dan $\mathrm{P}$ tersedia. Berdasarkan hasil analisis dikaitkan dengan kriteria status kesuburan tanah maka lokasi penelitian termasuk dalam status sedang dan tinggi. Status kesuburan meningkat menjadi tinggi setelah pemanenan. Hasil lengkapnya dapat dilihat pada Tabel 6 dan 7 .

Status kesuburan tanah pada masing-masing plot sebelum dilakukan penanaman tanaman sayuran termasuk dalam kategori sedang. Namun secara keselurahn bila digabungkan termasuk dalam kategori tinggi. Status kesuburan tanah mengalami peningkatan setelah penanaman tanaman sayuran masuk dalam kategori tinggi kecuali untuk plot agroforestri sayuran dengan eucalyptus umur 6 tahun. Kapasitas tukar kation dan kejenuhan basa menjadi penyebab status kesuburan tanah tersebut sedang.

\section{PEMBAHASAN}

PH merupakan reaksi tanah yang menunjukkan kemasaman atau alkalinitas tanah. $\mathrm{pH}$ tanah berperan penting dalam menentukan mudah tidaknya unsur-unsur hara diserap oleh tanaman. Unsur hara pada umumnya dapat diserap dengan baik oleh tanaman pada $\mathrm{pH}$ netral. Mikroorganisme tanah dan jamur dapat berkembang dengan baik pada $\mathrm{pH}$ di atas 5.5 jika kurang maka akan terhambat aktivitasnya. $\mathrm{pH}$ tanah yang rendah akan menyebabkan tanaman tidak dapat memanfaatkan $\mathrm{N}, \mathrm{P}$, $\mathrm{K}$, dan zat hara lain yang dibutuhkan. $\mathrm{pH}$ yang rendah juga menyebabkan tersedianya unsur beracun seperti alumunium yang selalu meracuni tanaman dan juga mengikat fosfor sehingga tidak bisa diserap oleh tanaman (Hardjowigeno 2007). pH tanah pada lokasi penelitian termasuk pada kategori agak masam yaitu berkisar 5.45-5.89. Pada masing-masing perlakuan $\mathrm{pH}$ tanah mengalami peningkatan setelah dilakukan penanaman kecuali pada plot kelas umur 2 tahun. Hasil penelitian memperlihatkan bahwa semakin tua umur tanaman eucalyptus $\mathrm{pH}$ tanah semakin tinggi, hal ini berbeda dengan penelitian Supangat (2013) yang menunjukan bahwa kenaikan umur tanaman Eucalyptus pellita tidak secara jelas mempengaruhi kenaikan ph tanah, namun dipengaruhi oleh lapisan tanah. Pada penelitian ini pengambilan tanah dilakukan secara komposit pada semua lapisan dengan kedalaman $30 \mathrm{~cm}$. $\mathrm{pH}$ tanah merupakan petunjuk ketersedian unsur hara bagi tanaman.

Kandungan bahan organik merupakan 1.724 x Corganik tanah. Bahan Organik Tanah (BOT) mempunyai peran penting dalam memperbaiki sifat fisik, kimia, dan biologi tanah dan secara langsung akan

Tabel 3 Hasil analisis sifat kimia tanah pada plot agroforestri umur 2 tahun

\begin{tabular}{|c|c|c|c|c|c|}
\hline \multirow{2}{*}{ No } & \multirow{2}{*}{ Parameter Pengujian } & \multirow{2}{*}{ Satuan } & \multicolumn{2}{|c|}{ Plot agroforestri umur 2 tahun } & \multirow{2}{*}{ Perubahan } \\
\hline & & & Sebelum & Setelah & \\
\hline 1 & $\mathrm{pH} \mathrm{H} \mathrm{H}_{2} \mathrm{O}$ & & $5.78(\mathrm{am})$ & 5.74(am) & -004 \\
\hline 2 & C-organik & $\%$ & $2.92(\mathrm{~s})$ & $2.56(\mathrm{~s})$ & -0.36 \\
\hline 3 & Rasio $\mathrm{C} / \mathrm{N}$ & & $8.86(\mathrm{r})$ & $9.15(\mathrm{r})$ & 0.29 \\
\hline 4 & $\mathrm{~N}$ total & & $0.33(\mathrm{~s})$ & $0.28(\mathrm{~s})$ & -0.05 \\
\hline 5 & $\mathrm{P}_{2} \mathrm{O}_{5}$ Tersedia & ppm & $31.09(\mathrm{~s})$ & $38.33(\mathrm{~s})$ & 7.24 \\
\hline 6 & $\mathrm{~K}_{2} \mathrm{O}$ & ppm & $202.55(\mathrm{st})$ & $398.55(\mathrm{st})$ & 196 \\
\hline 7 & $\mathrm{Ca}$ & me & $9.50(\mathrm{~s})$ & $12.89(\mathrm{t})$ & 3.39 \\
\hline 8 & $\mathrm{Mg}$ & me & $2.94(\mathrm{t})$ & $5.69(\mathrm{t})$ & 2.75 \\
\hline 9 & K & me & $0.25(\mathrm{~s})$ & $0.59(\mathrm{t})$ & 0.34 \\
\hline 10 & $\mathrm{Na}$ & me & $0.29(\mathrm{r})$ & $0.22(\mathrm{r})$ & -0.07 \\
\hline 11 & KTK & me & $26.79(t)$ & $27.19(\mathrm{t})$ & 0.4 \\
\hline 12 & $\mathrm{~KB}$ & $\%$ & 48.49(s) & $71.34(\mathrm{st})$ & 22.85 \\
\hline
\end{tabular}

$\mathrm{m}$ : masam, am: agak masam, $\mathrm{r}$ : rendah, $\mathrm{s}:$ sedang t: tinggi $\mathrm{st}:$ sangat tinggi

Tabel 4 Hasil analisis sifat kimia tanah pada plot agroforestri umur 4 tahun

\begin{tabular}{|c|c|c|c|c|c|}
\hline \multirow{2}{*}{ No } & \multirow{2}{*}{ Parameter Pengujian } & \multirow{2}{*}{ Satuan } & \multicolumn{2}{|c|}{ Plot Agroforestri umur 4 tahun } & \multirow{2}{*}{ Perubahan } \\
\hline & & & Sebelum & Setelah & \\
\hline 1 & $\mathrm{pH} \mathrm{H} \mathrm{H}_{2} \mathrm{O}$ & & $5.54(\mathrm{am})$ & $5.78(\mathrm{am})$ & 0.24 \\
\hline 2 & C-organik & $\%$ & $2.47(\mathrm{~s})$ & $3.20(\mathrm{t})$ & 0.73 \\
\hline 3 & Rasio C/N & & $8.07(\mathrm{r})$ & $8.90(r)$ & 0.83 \\
\hline 4 & $\mathrm{~N}$ total & & $0.31(\mathrm{~s})$ & $0.36(\mathrm{~s})$ & 0.05 \\
\hline 5 & $\mathrm{P}_{2} \mathrm{O}_{5}$ Tersedia & ppm & $11.95(\mathrm{r})$ & $131.06(\mathrm{st})$ & 119.11 \\
\hline 6 & $\mathrm{~K}_{2} \mathrm{O}$ & ppm & $213.17(\mathrm{st})$ & $918.93(\mathrm{st})$ & 705.76 \\
\hline 7 & $\mathrm{Ca}$ & me & $10.51(\mathrm{~s})$ & $10.99(\mathrm{~s})$ & 0.48 \\
\hline 8 & $\mathrm{Mg}$ & me & $4.05(\mathrm{t})$ & $4.41(\mathrm{t})$ & 0.36 \\
\hline 9 & K & me & $0.52(\mathrm{t})$ & $2.09(\mathrm{st})$ & 1.57 \\
\hline 10 & $\mathrm{Na}$ & me & $0.35(\mathrm{~s})$ & $0.20(\mathrm{r})$ & -0.15 \\
\hline 11 & KTK & me & $17.12(\mathrm{~s})$ & $24.08(\mathrm{~s})$ & 6.96 \\
\hline 12 & $\mathrm{~KB}$ & $\%$ & $90.07(\mathrm{st})$ & $73.45(\mathrm{st})$ & -16.62 \\
\hline
\end{tabular}

$\mathrm{m}$ : masam, am: agak masam, $\mathrm{r}:$ rendah, $\mathrm{s}:$ sedang, t: tinggi, st : sangat tinggi 
mempengaruhi tingkat kesuburan tanah, selain itu kandungan bahan organik juga merupakan salah satu indikator tingkat kesuburan tanah. Kandungan C-org secara tidak langsung menunjukkan produksi bahan organik pada lokasi penelitian (Susanto 2005, Rahmat 2016). C-organik pada plot penelitian termasuk kategori sedang pada plot monokultur, agroforestri umur 2 tahun dan agroforestri umur 4 tahun. Pada plot agroforestri umur 6 tahun termasuk dalam kategori sangat tinggi. Corganik mengalami kenaikan pada saat sebelum dan sesudah penanaman kecuali pada plot agroforestri umur 2 tahun. Kenaikan C-organik disebabkan oleh adanya penambahan pupuk kandang.

Widyantari (2015) menyatakan bahwa adanya vegetasi akan menambah kandungan bahan organik, hal inilah yang menyebabkan kandungan bahan organik pada plot agroforestri umur 6 tahun lebih banyak dibandingkan dengan umur 2 dan 4 karena jumlah seresah yang dihasilkan juga lebih banyak. Kualitas bahan organik diukur dengan $\mathrm{C} / \mathrm{N}$. $\mathrm{C} / \mathrm{N}$ berkaitan dengan laju humifikasi dan mineralisasi yang dilakukan oleh mikroorganisme tanah. $\mathrm{C} / \mathrm{N}$ menunjukan baik atau tidaknya penguraian bahan organik. $\mathrm{C} / \mathrm{N}$ pada plot penelitian termasuk dalam kategori rendah. Peningkatan umur tanaman eucalyptus menunjukan terjadinya peningkatan kandungan bahan organik, hal ini senada dengan kandungan bahan organik pada tanah dibawah eucalyptus pelita dimana semakin tua umur eucalyptus pelita memperlihatkan peningkatan bahan organik tanah (Supangat 2013).

Nitrogen $(\mathrm{N})$ mempunyai peran penting bagi pertumbuhan tanaman. Nitrogen dapat diserap tanaman

Tabel 5 Hasil analisis sifat kimia tanah pada plot agroforestri umur 6 tahun

\begin{tabular}{|c|c|c|c|c|c|}
\hline \multirow{2}{*}{ No } & \multirow{2}{*}{ Parameter Pengujian } & \multirow{2}{*}{ Satuan } & \multicolumn{2}{|c|}{ Plot Agroforestri umur 4 tahun } & \multirow{2}{*}{ Perubahan } \\
\hline & & & Sebelum & Setelah & \\
\hline 1 & $\mathrm{pH} \mathrm{H} \mathrm{H}_{2} \mathrm{O}$ & & $5.63(\mathrm{am})$ & $5.89(\mathrm{am})$ & 0.26 \\
\hline 2 & C-organik & $\%$ & $6.69(\mathrm{st})$ & $6.91(\mathrm{st})$ & 0.22 \\
\hline 3 & Rasio $\mathrm{C} / \mathrm{N}$ & & $9.35(\mathrm{r})$ & $11.25(\mathrm{~s})$ & 1.9 \\
\hline 4 & $\mathrm{~N}$ total & & $0.71(\mathrm{t})$ & $0.61(\mathrm{t})$ & -0.1 \\
\hline 5 & $\mathrm{P}_{2} \mathrm{O}_{5}$ Tersedia & ppm & $84.03(\mathrm{st})$ & $112.49(\mathrm{st})$ & 28.48 \\
\hline 6 & $\mathrm{~K}_{2} \mathrm{O}$ & ppm & $313.872(\mathrm{st})$ & $1000.4(\mathrm{st})$ & 686.528 \\
\hline 7 & $\mathrm{Ca}$ & me & $7.59(\mathrm{~s})$ & $8.97(\mathrm{~s})$ & 1.38 \\
\hline 8 & $\mathrm{Mg}$ & me & $1.24(\mathrm{~s})$ & $1.77(\mathrm{~s})$ & 0.53 \\
\hline 9 & $\mathrm{~K}$ & me & $0.23(\mathrm{~s})$ & $0.61(\mathrm{t})$ & 0.38 \\
\hline 10 & $\mathrm{Na}$ & me & $0.29(\mathrm{r})$ & $0.15(\mathrm{r})$ & -0.14 \\
\hline 11 & KTK & me & $23.75(\mathrm{~s})$ & $24.31(\mathrm{~s})$ & 0.56 \\
\hline 12 & $\mathrm{~KB}$ & $\%$ & $39.37(\mathrm{~s})$ & 47.35(s) & 7.98 \\
\hline
\end{tabular}

Tabel 6 Status kesuburan tanah sebelum penanaman berdasarkan petunjuk teknis evaluasi kesuburan tanah

\begin{tabular}{ccccccc}
\hline \multirow{2}{*}{ Plot } & \multicolumn{3}{c}{ Jenis Analisis } & \multirow{2}{*}{ Status kesuburan } \\
\cline { 2 - 5 } & $\mathrm{KTK}$ & $\mathrm{KB}$ & $\mathrm{P}_{2} \mathrm{O}_{5}$ & $\mathrm{~K}_{2} \mathrm{O}$ & $\mathrm{C}-\mathrm{Org}$ & \\
\hline $\mathrm{A} 0$ & $31.21(\mathrm{t})$ & $78.82(\mathrm{st})$ & $15.20(\mathrm{r})$ & $124.34(\mathrm{st})$ & $2.09(\mathrm{~s})$ & Sedang \\
$\mathrm{A} 1$ & $26.79(\mathrm{t})$ & $48.49(\mathrm{~s})$ & $31.09(\mathrm{~s})$ & $202.55(\mathrm{st})$ & $2.92(\mathrm{~s})$ & Sedang \\
$\mathrm{A} 2$ & $17.12(\mathrm{~s})$ & $90.07(\mathrm{st})$ & $11.95(\mathrm{r})$ & $213.17(\mathrm{st})$ & $2.47(\mathrm{~s})$ & Sedang \\
A3 & $23.75(\mathrm{~s})$ & $39.37(\mathrm{~s})$ & $84.03(\mathrm{st})$ & $313.87(\mathrm{st})$ & $6.69(\mathrm{st})$ & Sedang \\
Rata-rata & 24.72 & 64.19 & 35.57 & 213.48 & 3.54 & Tinggi \\
Status kesuburan & $\mathrm{S}$ & $\mathrm{T}$ & $\mathrm{ST}$ & $\mathrm{ST}$ & $\mathrm{T}$ & T
\end{tabular}

A0 plot monokultur sayuran; A1 plot agroforestri sayuran dan eucalyptus umur 2 tahun; A2 plot agroforestri sayuran dan eucalyptus umur 4 tahun; A3 plot agroforestri sayuran dan eucalyptus umur 6 tahun; S1 sebelum penanaman; S2 setelah panen; $r$ : rendah, $\mathrm{s}$ : sedang, $\mathrm{t}$ : tinggi, st : sangat tinggi

Tabel 7 Status kesuburan tanah setelah penanaman berdasarkan petunjuk teknis evaluasi kesuburan tanah

\begin{tabular}{|c|c|c|c|c|c|c|}
\hline \multirow{2}{*}{ Plot } & \multicolumn{5}{|c|}{ Jenis Analisis } & \multirow{2}{*}{$\begin{array}{c}\text { Status } \\
\text { kesuburan }\end{array}$} \\
\hline & KTK & $\mathrm{KB}$ & $\mathrm{P}_{2} \mathrm{O}_{5}$ & $\mathrm{~K}_{2} \mathrm{O}$ & C-Org & \\
\hline A0 & $25.84(\mathrm{t})$ & $72.02(\mathrm{st})$ & $26.34(\mathrm{~s})$ & $293.43(\mathrm{st})$ & $2.67(\mathrm{~s})$ & Tinggi \\
\hline A1 & $27.19(\mathrm{t})$ & 71.34(st) & $38.33(\mathrm{~s})$ & $398.55(\mathrm{st})$ & $2.56(\mathrm{~s})$ & Tinggi \\
\hline $\mathrm{A} 2$ & $24.08(\mathrm{~s})$ & $73.45(\mathrm{st})$ & $131.06(\mathrm{st})$ & $918.93(\mathrm{st})$ & $3.20(\mathrm{t})$ & Tinggi \\
\hline A 3 & $24.31(\mathrm{~s})$ & $47.35(\mathrm{~s})$ & $112.49(\mathrm{st})$ & $1000.4(\mathrm{st})$ & $6.91(\mathrm{st})$ & Sedang \\
\hline Rata-rata & 25.36 & 66.04 & 77.05 & 652.83 & 3.84 & \\
\hline Status kesuburan & $\mathrm{T}$ & $\mathrm{T}$ & ST & ST & $\mathrm{T}$ & Tinggi \\
\hline
\end{tabular}

A0 plot monokultur sayuran; A1 plot agroforestri sayuran dan eucalyptus umur 2 tahun; A2 plot agroforestri sayuran dan eucalyptus umur 4 tahun; A3 plot agroforestri sayuran dan eucalyptus umur 6 tahun; S1 sebelum penanaman; S2 setelah panen; $\mathrm{r}$ : rendah, $\mathrm{s}$ : sedang, t: tinggi, st : sangat tinggi 
dari dalam tanah dalam bentuk $\mathrm{NH}_{4}{ }^{+}$dan $\mathrm{NO}_{3}{ }^{-} . \mathrm{N}$ total merupakan unsur makro yang dibutuhkan tanaman dalam jumlah yang banyak dan menyusun $1.5 \%$ bobot tanaman. $\mathrm{N}$ berfungsi dalam pembentukan protein (Hanafiah 2009). Ketersediaan nitrogen pada lokasi penelitian termasuk dalam kategori sedang, kecuali plot agroforestri umur 6 tahun masuk kategori tinggi. Kenaikan nitrogen pada kelas umur terlihat dimana kelas umur 6 tahun mempunyai kandungan $\mathrm{N}$ lebih tinggi dibandingkan dengan umur 2 dan 4 tahun. Banyaknya $\mathrm{N}$ tanah tergantung dari keadaan lingkungannya seperti iklim, dan macam vegetasi. Vegetasi yang tumbuh di atas tanah dan kecepatan dekomposisinya merupakan faktor penyebab perubahan terhadap kandungan N dalam tanah (Supangat 2013, Rahmi 2014).

Kandungan fosfor (P) di dalam penelitian ini termasuk dalam kategori rendah sampai dengan tinggi. Pada plot monokultur tanaman sayuran termasuk dalam kategori rendah pada saat awal penanaman namun adanya pemupukan saat penanaman membuat kandungan fosfor pada saat panen menjadi tinggi. Pada plot agroforestri kandungan bahan organik masuk dalam kategori sedang pada umur 2 dan 6 tahun sedangkan pada umur 4 masuk kategori rendah. Kandungan fosfor meningkat dengan adanya penanaman sehingga pada saat panen masuk kategori tinggi. Fosfor merupakan unsur makro esensial yang kedua setelan nitrogen yang sangat dibutuhkan tanaman yang berfungsi dalam pembelahan sel, pembentukan albumin, pembentukan bunga, buah dan biji, mempercepat pematangan dan memperkuat batang tidak mudah roboh. Unsur fosfor dalam tanah berasal dari bahan organik, mineral-mineral tanah dan pupuk buatan (Herawati 2015).

Kalium $(\mathrm{K})$ pada lokasi penelitian tergolong sangat tinggi. Unsur $\mathrm{K}$ yang digunakan oleh tanaman hanya sebagian kecil. Kalium yang terlarut dan kalium yang dipertukarkan adalah kalium yang dianggap tersedia. Herawati (2015) menjelaskan bahwa ion $\mathrm{k}$ tergolong unsur yang mudah bergerak sehingga mudah sekali hilang dari tanah melalui pencucian, karena $\mathrm{K}$ tidak ditahan kuat oleh permukaan koloid tanah. Sifak K yang mudah hilang dari tanah menyebabkan efisiensinya rendah seperti halnya unsur N. Penyebab tinggi rendahnya kalium dalam tanah dipengaruhi oleh bahan induk dan juga $\mathrm{pH}$ tanah. $\mathrm{pH}$ tanah yang masam akan menyebabkan peningkatan fiksasi kalium sehingga menyebabkan penurunan ketersediaan unsur $\mathrm{K}$ dalam tanah.

Selain unsur nitrogen, fosfor dan kalium unsur hara makro yang penting lainnya adalah Calsium (Ca), Magnesiun ( $\mathrm{Mg}$ ) dan Natrium (Na) tersedia sangat penting untuk pertumbuhan tanaman. Hasil analisis sifat kimia tanah menunjukan bahwa lokasi penelitian mempunyai kandungan Calsium sedang sampai tinggi, Magnesium sedang sampai tinggi dan Natrium rendah sampai sedang. Keberadaan unsur-unsur hara tersebut cukup dapat menyeimbangan kesuburan tanah. Unsur P ketersediannya dipengaruhi oleh unsur $\mathrm{Ca}$, kelarutan $\mathrm{Ca}$ yang banyak akan mengurangi ketersediaan $\mathrm{P}$ menjadi tidak tersedia. Ketersediaan unsur hara $\mathrm{Ca}$ dan $\mathrm{Mg}$ bersifat sinergis, semakin tinggi kelarutan $\mathrm{Ca}$ diikuti oleh kelarutan Mg yang tinggi juga (Castan et al. 2016).
Kapasitas tukar kation (KTK) merupakan salah satu sifat kimia tanah yang berkaitan erat dengan ketersediaan hara bagi tanaman dan menjadi indikator kesuburan tanah. KTK adalah kapasitas lempung untuk menjerap dan menukar kation. KTK dipengaruhi oleh kandungan liat, tipe liat dan kandungan bahan organik. KTK tanah menggambarkan kation-kation tanah seperti aktion $\mathrm{Ca}, \mathrm{Mg}, \mathrm{Na}$, dan dapat ditukar dan diserap oleh perakaran tanaman(Herawati 2015). Hasil analisis menunjukkan bahwa KTK pada lokasi penelitian termasuk tinggi pada plot monokultur dan agroforestri umur 2 tahun, sedangkan agroforestri umur 4 dan 6 tahun masuk kategori sedang. KTK pada saat panen mengalami kenaikan jika dibandingkan dengan saat awal penanaman. Penambahan pupuk pada saat penanaman merupakan salah satu sebab kenaikan KTK pada lokasi penelitian. Selain KTK kejenuhan basa juga menentukan kesuburan tanah. Kejenuhan basa merupakan perbandingan antara jumlah kation basa yang ditukarkan dengan kapasitas tukar kation (KTK) tanah yang dinyatakan dalam persen. Kejenuhan basa pada lokasi penelitian termasuk dalam kategori sedang dan sangat tinggi. Nilai KTK tanah biasanya berbanding lurus dengan kejenuhan basa (KB) tanah, karena kejenuhan basa merupakan gambaran tingginya jumlah kation pada kompleks koloid tanah (Bohnet 2009).

Berdasarkan hasil analisis dikaitkan dengan kriteria status kesuburan tanah maka lokasi penelitian termasuk dalam status sedang dan tinggi. Penambahan pupuk organik saat penanaman sayuran mampu meningkatkan status kesuburan menjadi tinggi setelah pemanenan. Pupuk organik memiliki sifat lambat tersedia. Sifat lambat tersedianya dari pupuk organik ini yang berpengaruh terhadap keadaan $\mathrm{pH}, \mathrm{C}$-org, $\mathrm{N}$-tot, $\mathrm{P}$ tersedia, KTK dan KB pada pengamatan saat panen (Nuro 2016).

\section{SIMPULAN}

Status kesuburan tanah secara kimia termasuk dalam kategori sedang pada semua plot baik monokultur maupun dibawah eucalyptus umur 2, 4, dan 6 tahun. Pola tanam Agroforestri mampu meningkatkan status kesuburan tanah secara kimia menjadi ketegori tinggi. Sebelum penanaman nilai rata-rata KTK adalah sebesar 24.72 me/100gr (sedang), Kejenuhan Basa 64.19\% (tinggi), $\mathrm{P}_{2} \mathrm{O}_{5} 35.57 \mathrm{me} / 100 \mathrm{gr}$ (sangat tinggi), $\mathrm{K}_{2} \mathrm{O}$ $213.48 \mathrm{me} / 100 \mathrm{gr}$ (sangat tinggi), dan C-org $3.54 \%$ (tinggi).Setelah panen nilai rata-rata KTK adalah sebesar 25.36 me/100gr (tinggi), Kejenuhan Basa $66.04 \%$ (tinggi), $\mathrm{P}_{2} \mathrm{O}_{5} 77.05 \mathrm{me} / 100$ gr (sangat tinggi), $\mathrm{K}_{2} \mathrm{O} 652.83 \mathrm{me} / 100 \mathrm{gr}$ (sangat tinggi), dan C-org $3.84 \%$ (tinggi).

\section{DAFTAR PUSTAKA}

Arifin Z. 2011. Analisis Indeks Kualitas Tanah Entisol pada Berbagai Penggunaan Lahan yang Berbeda. Agroteksos Vol. 21(1): 47-54.

Bhatt BP, Todaria NP. 1990. Studies on the allelopathic effects of some agroforestry tree crops of Garhwal Himalaya. Jurnal Agroforest System 12: 251-255. 
Bohnet B. 2009. Efficient Parsing Of Syntactic And Sematic Dependency Structures. In Proceeding of CoNLL-09.

Castan E, Satti P, Gonzales PM, Iglesias MC, Mazzarino MJ. 2016. Managing the Value of Compost as Organic Amendment and Fertilizers in Sandy Soils. Agriculture, Ecosystems and Environment. 224:29-38.

Effendi S. 1995. Ilmu Tanah. Jakarta (ID): PT. Mediyana Sarana Perkasa.

Fathurrohmah RA, Wijayanto N. 2014. Pengaruh Pohon Penaung Eukaliptus (Eucalyptus deglubta B1.) dan Suren (Toona sureni Merr.) Terhadap Pertumbuhan dan Produksi Kopi (Coffea arabica L.). Prosiding Seminar Nasional Agroforestri ke-5. Ambon (ID): BPTA - UNPATI..

[FAO] Food and Agricultural Organitation. 2006. Agroforestry System. http://www.fao.org/forestry/tof/50667/en/. Diakses tanggal 2 Maret 2017

Hairiah K, Widianto, Utami SR, Suprayogo D, Sitompul SM, Lusisna B, Mulia R, van Noordwijk M dan Cadisch G. 2000. Pengelolaan tanah masam secara biologi : refleksi pengalaman dari Lampung Utara. Bogor (ID): International Center For Research in Agroforestry.

Hanafiah K. 2009. Dasar-dasar Ilmu Tanah. Jakarta (ID): Raja Grafindo Perkasa.

Handoko. 1995. Klimatologi Dasar. Jakarta (ID): Pustaka Jaya.

Hardjowigeno S. 2007. Ilmu Tanah. Jakarta(ID): Pusaka Utama.

Herawati MS. 2015. Kajian Status kesuburan Tanah di Lahan Kakao Kampung Klain Distrik Mayamuk Kabupaten Sorong. Jurnal Agroforestri. Edisi X: 201-208

[KLHK] Kementerian Lingkungan Hidup dan Kehutanan. 2017. Pemerintah Konsisten Tangani Rehabilitasi Eks Banjir Garut. http://www.menlhk.go.id/berita-268-pemerintahkonsisten-tangani-rehabilitasi-eks-banjirgarut.html. [internet]. Diakses 10 Januari 2018

Koesmawardhani NW. 2017 Februari 26. Ini Analisis KLHK Soal Banjir di 5 Wilayah. http://www.detik.com. [internet] Garut Berduka. Diakses tanggal 31 Maret 2017

Lisanework N, Michelsen A. 1993. Allelopathy in agroforestry systems - the effects of leaf extracts of Cupressus-Lusitanica and 3 Eucalyptus spp. On 4 Ethiopian crops. Agroforestery System 21: 63-74

Malik MS. 2004. Effects of aqueous leaf extracts of Eucalyptus globulus on germination and seedling growth of potato, maize and bean. Allelopathy Journal 14: 213-219.

Masnurdiansyah. 2016 September 22. Ekploitasi Hulu Sungai Cimanuk Jadi Salah Satu Penyebab Banjir
Bandang Garut. detik.com. Garut Berduka. Diakses 3 April 2017

Moradshahi A, Ghadiri H, Ebrahimikia F. 2003. Allelopathic effects of crude volatile oil and aqueous extracts of Eucalyptus camaldulensis Dehnh. leaves on crops and weeds. Allelopathy Journal 12 : 189-195.

Nuro F, Priadi D, Sri EM, 2016. Efek Pupuk Organik Terhadap Sifat Kimia Tanah dan Produksi Kangkung Darat (Ipomoea reptans Poir). Prosiding Seminar Nasional Hasil-hasil PPM IPB 2016. 29-39

[PPT] Pusat Penelitian Tanah. 1995. Petunjuk Teknis Evaluasi Kesuburan Tanah. Laporan Teknis No.14. Versi 1,0.1. REP II Project, CSAR, Bogor.

Pujiwinarko A. 2015. Model Agroforestri Pengelolaan Hutan Bersama Masyarakat (PHBM) Di Hutan Lindung Dataran Tinggi Dieng [tesis]. Bandung (ID): Universitas Padjadjaran.

Rahmat MH, Sufardi, Khalil M. 2016. Evaluasi Kesuburan Pada Beberapa Jenis Tanah di Lahan Kering Kabupaten Pidie Provinsi Aceh. Jurnal Ilmiah Mahasiswa Pertanian Unsyiah. Vol. 1 (1): 147-154.

Rahmi A, Preva MB. 2014. Karakteristik Sifat Kimia Tanah Dan Status Kesuburan Tanah Laha Pekarangan Dan Lahan Usaha Tani Beberapa Kampung Di Kabupaten Kutai Barat. Ziraa'ah. Vol 39 (1): 30-36

Sabarnurdin MS, Suryanto P, Aryono WB. 2004. Dinamika Pohon Mahoni (Swietenia macrophylla King) pada Agroforestry Lorong (Alley Cropping. Jurnal Ilmu Pertanian Vol. 11 (1):63-73.

Sanchez PA. 1995. Science in Agroforestry. Jurnal Agroforestry System 30: 5-55.

Supangat AB, Supriyo H, Sudira P, Poedjirahajoe E. 2013. Status Kesuburan Tanah di Bawah Tegakan Eucalyptus pellita F.Muell: Studi Kasus di HPHTI PT.ARARA ABADI, RIAU. Jurnal Manusia dan Lingkungan. Vol 20 (1): 22-34.

Suryanto P, Aryono WB, Sabarnurdin MS. 2006. Model Bera Dalam Sistem Agroforestri (Fallow Land Model in Agroforestry Systems). Jurnal Manajemen Hutan Tropika Vol. XII (2): 15-26

Susanto AN. 2005. Pemetaan Dan Pengelolaan Status Kesuburan Tanah Di Dataran Wai Apu, Pulau Buru. Jurnal Pengkajian dan Pengembangan Teknologi Pertanian Vol. 8 (3): 315-332.

Susila AD. 2006. Panduan Budidaya Tanaman Sayuran. Bagian Produksi Tanaman Departemen Agronomi dan Hortikultura. Bogor (ID): Institut Pertanian Bogor.

Widyantari DAG, Dharma KS, Tatiek K. 2015. Evaluasi Status Kesuburan Tanah untuk Lahan Pertanian di Kecamatan Denpasar Timur. E-Jurnal Agroekoteknologi. Vol 4 (4): 293-303. 